\title{
TEACHERS PERCEPTION ABOUT EPILEPSY
}

\author{
Paula T. Fernandes ${ }^{1,2}$, MSc, PhD; Ana L.A. Noronha ${ }^{1,2}, M D$, PhD; Ulisses Araújo ${ }^{3}$, PhD; \\ Paula Cabral4; Ricardo Pataro4; Hanneke M. de Boer ${ }^{5,6}$; Leonid Prilipko ${ }^{5,7}$, MD; \\ Josemir W. Sander ${ }^{6,8}, M D, P h D, F R C P$; Li M. Li ${ }^{1,2}, M D, P h D$
}

\begin{abstract}
Purpose: To identify in a town of Brazil the knowledge, attitude and perception of epilepsy in teachers of elementary schools and to compare these before and after a training exercise. Methods: Teachers of nine public schools of Barão Geraldo, Campinas, Brazil completed a questionnaire. Two researchers had meetings with teachers, presenting the Global Campaign "Epilepsy out of the shadows", when the questionnaire was first completed by all attendees. Twenty teachers of these schools were motivated to attend a training course entitled "Epilepsy and Health" as part of their continuous education programme. Two years later the same questionnaire was again completed (post-test) by these 20 teachers. Results: 100 teachers originally completed the questionnaire (97 women, mean age 42 years, 64 married). Forty-three percent of teachers said that they had enough knowledge rega rding epilepsy and $20 \%$ said that they had poor knowledge about the condition. Regarding the IQ of children with epilepsy, $45 \%$ of teachers believed that they had average IQ, 18\% above average, six percent under average and $29 \%$ did not know. Teachers believed that children with epilepsy have a higher possibility of acquiring mental disease in the future (51\%); that epilepsy is a disease (68\%); that epilepsy is contagious (1\%); epilepsy is treatable $(90 \%)$. After the course, the teachers' beliefs seem to have improved. Discussion: This work with elementary school teachers identified difficulties related to epilepsy which, if addressed, may help promote better quality of life of people with epilepsy in the community and help to decrease stigma attached to the condition. Better informed teachers are likely to have a more positive attitude and this will be passed to others. Educational campaigns about epilepsy amongst teachers should be encouraged as this may improve the management of epilepsy, by helping to develop a well informed and tolerant community.
\end{abstract}

KEY WORDS: epilepsy, stigma, school, teachers.

\begin{abstract}
Percepção de professores sobre epilepsia
RESUMO - Objetivo: Identificar atitudes e percepção dos professo resdo ensino fundamental a respeito da epilepsia, antes e depois de um curso específico sobre o tema. Método: Pa rticiparam da pesquisa professores de nove escolas da rede pública do ensino fundamental de Barão Geraldo, distrito de Campinas, SP. Dois pesquisadores reuniram-se com os professores e apresentaram a Campanha Global "Epilepsia fora das sombras", momento também em que os questionários foram aplicados. Vinte professores ficaram motivados para fazer o curso de extensão "Temas transversais: epilepsia e saúde". Após este curso, os questionários foram re-aplicados. Resultados: Foram aplicados 100 questionários em professores das nove escolas, sendo que: noventa e sete professores eram do sexo feminino, idade média de 42 (D.P. 22 a 63) e 64 estavam casados. Quarenta e três professo resdeclararam possuir conhecimento sobre epilepsia abaixo da média e 20, disseram possuir um pobre conhecimento sobre a condição. No que diz respeito à idéias sobre epilepsia, os professores acham que: as crianças com epilepsia tem QI igual (45\%), na média (18\%), abaixo da média (6\%) e não sabem opinar (29\%); crianças com epilepsia têm maior chance de terem doença mental no futuro (51\%); a epilepsia é uma doença ( $68 \%)$; a epilepsia é contagiosa ( $1 \%$ ); a epilepsia é tratável $(90 \%)$. Após o curso, crenças e mitos sobre epilepsia dos professores mostraram diferenças significativas. Discussão: Idéias errôneas sobre epilepsia podem ser mudadas através de cursos educacionais sobre epilepsia. Este trabalho, realizado com professores do ensino fundamental, visou a identificação das dificuldades relacionadas à epilepsia para promover a redução do estigma. É importante que professores sejam melhor instruídos sobre a epilepsia para consequentemente, ter atitudes mais positivas em relação às crianças com epilepsia. Acreditamos que professo resmais capacitados melhoram a maneira de lidar e de se relacionar com crianças com epilepsia, para a construção de uma comunidade bem informada e mais tolerante para lidar com as diferenças.
\end{abstract}

PALAVRAS-CHAVE: epilepsia, estigma, escola, professores.

\footnotetext{
'Department of Neurology, Faculty of Medicine, UNICAMP, Campinas, SP, Brazil; ${ }^{2}$ Assistência à Saúde de Pacientes com Epilepsia -

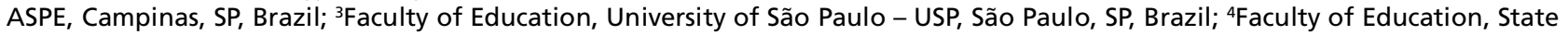
University of Campinas - UNICAMP, Campinas, SP, Brazil; ${ }^{5}$ Global Campaign Against Epilepsy Secretariat, Geneva, Switzerland; ${ }^{6}$ Epilepsy Institute of the Netherlands, SEIN, Heemstede, Achterweg 5, 2103 SW Heemstede, the Netherlands; ${ }^{7}$ Department of Mental Health and Substance Abuse World Health Organization, Geneva, Switzerland; ${ }^{8}$ Department of Clinical and Experimental Epilepsy, UCL Institute of Neurology, London UK
} 
Children spend a lot of time at school, and in those with a chronic condition such as epilepsy the severity of that condition can influence their school experience 1 . Studies have shown that children with epilepsy are more prone to difficulties in school and to behavioural problem s-4. However, it is difficult to say whether these difficulties are related to seizures, to antiepileptic drugs or to social relationships with their teachers and friends or multifactorial ${ }^{5}$.

Epilepsy is a relatively common chronic condition in school-age childre $n^{6}$. The implications of epilepsy are general, affecting behaviour, psychosocial adjustment and quality of life of sufferers and their families $^{7-10}$. These negative implications are often related to discrimination and the stigma which exists in our society ${ }^{10-14}$.

Many people have irrational beliefs about epilepsy mainly because of lack of information. Some people do not know how to deal with a seizure; others believe that it is contagious or that it may cause learning disabilities or other conditions ${ }^{15-20}$. All of these inappropriate ideas are culturally reinforced and can $p$ romote negative feelings and behaviours towards people with epilepsy ${ }^{8}$.

These beliefs are very common in schools. Children with epilepsy experience these erroneous attitudes mainly in social environments such as schools ${ }^{21,22}$. School routine may change when there is a child with epilepsy in the classroom ${ }^{1}$. There is a high prevalence of epilepsy in school age children, and many do not perform well at school, presenting with difficulties in learning and social interactions. These difficulties may be related not only to epilepsy factors (age at first seizure, severity of epilepsy, aetiology and tre atment, frequency and type of seizures, medications), but also to psychological factors, such as quality of education, low expectations and rejection by teachers and parents, and low self-esteem of the child ${ }^{11,13}$.

In elementary school, teachers are important examples to children and have a lifelong influence. Thus teachers' attitudes may impact the educational perf o rmance of children, particularly those with epilepsy $^{20}$.

In this context, assessment of the perception of elementaryeducation teachers is important. Little is known about what teachers think about children with epilepsy in their classrooms. For the process of learning and relationships of children at school favourable conditions must exist ${ }^{9}$. Understanding the ideas and behaviour of teachers regarding this should allow the formulation of measures to improve the experience of children with epilepsy at school. This should also help to improve the understanding of epilepsy at community level as teachers usually have an influence which extends beyond the school boundaries. This study is a part of phase II of the National Demonstration Project on Epilepsy part of the Global Campaign Epilepsy Out of the Shadows-WHO-ILAEIBE in Brazil, executed by ASPE, Assistência à Saúde de Pacientes com Epilepsia ${ }^{23}$, aims to assess knowledge, attitude and perception of epilepsy amongst elementaryschool teachers in a Brazilian town and to compare these before and after an educational course.

\section{METHOD}

Subjects - Two groups of teachers from nine public schools in the town of Barão Geraldo (Campinas municipality), São Paulo State,

Instrument - The questionnaire, completed by two groups of subjects (before and after a course), is part of the Demonstrative Project of the Global Campaign "Epilepsy out of the Shadows" and is divided in three parts:

Part I: Knowledge about epilepsy and its treatment (nine questions).

Part II: Attitudes towards epilepsy (fifteen questions).

Part III: Perceptions re ga rding epilepsy (23 questions), using a scale with possible answers from 1 (I totally agree) to 5 (I totally disagree).

The questionnaire contains data related to the teachers' demographic information (age, religion, civil status, number of students, period of work, etc.).

The questionnaire was developed following a standard process for elaboration and validation ${ }^{24}$. Briefly, the steps of the process are the following:

- Definition of the theme of interest: We undertook a literature review, and established the current knowledge of the theme epilepsy and education.

- Delimitation of population: elementary school teachers.

- Definition of item: We defined which type of possible answer (for example, multiple choice, true or false, scale) would best fit each question.

- Elaboration of instrument: The items of the questionnaire were elaborated by a panel of experts in the field of epilepsy and education. The elaboration of the questionnaire was aimed to assess general knowledge on epilepsy, attitudes and perceptions.

Proce d u re-The questionnaire was completed by 100 teachers of nine public schools of Barão Geraldo (pre-test). Two re se a rchers (PC, RP) had meetings with the teachers, $p$ resenting the Global Campaign, during which the questionnaire was self completed.

Twenty of these teachers were motivated to attend the training course "Epilepsy and Health" as part of their continuous education programme. After two years the same questionnairewas completed (post-test) by these 20 teachers. The course was of 20 hours duration divided in two 
parts: one on epilepsy (eight hours) and one on educational methods to use in class on the theme of epilepsy.

\section{RESULTS}

The characterization of subjects of two phases is showed in Table 1.

\section{Part I and II (knowledge and attitudes)}

Group 1 (prior to the course) - Forty-three percent of teachers felt that they had enough knowledge regarding epilepsy and $20 \%$ accepted that they had a poor knowledge. Subjects said that the most informative sources were newspapers and magazine articles (53\%), television (29\%) and school (22\%).

Most teachers (79\%) had seen a seizure and $19 \%$ teachers had never seen one. Fourteen percent of teachers believed that some of their students have epilepsy, 33\% did not know; 35\% knew they had previously had students with epilepsy in their classrooms and $50 \%$ stated that they had never taught a student with epilepsy.
Eighty-nine percent of teachers answered that they would like to learn more about epilepsy and $78 \%$ said that the government should act more effectively with this condition.

$G$ roup 2 (after the course) - Seventy-five percent of teachers felt that they had enough knowledge regarding epilepsy and no one admitted poor knowledge about the condition. Subjects said that the most informative sources were newspapers and magazine articles (65\%), own study (40\%), school (55\%) and contact with doctors (30\%).

Fifty-five percent of teachers had seen a seizure and $40 \%$ of them had never seen one. Twenty percent of teachers believed that some of their students have epilepsy, 25\% did not know; 35\% knew they had previously had students with epilepsy in their classrooms and $50 \%$ stated that they had never taught a student with epilepsy.

Ninety-five percent of teachers answered that they would like to learn more about epilepsy and the

Table 1. Characterization of subjects.

\begin{tabular}{|c|c|c|}
\hline $\begin{array}{l}\text { Teachers' } \\
\text { characteristics }\end{array}$ & $\begin{array}{c}\text { Pre-test }(n=100) \\
\%\end{array}$ & $\begin{array}{c}\text { Post-test }(n=20) \\
\%\end{array}$ \\
\hline Mean age & $42(22-63)$ & $39(23-59)$ \\
\hline \multicolumn{3}{|l|}{ Sex } \\
\hline Male & 3 & 5 \\
\hline Female & 97 & 95 \\
\hline \multicolumn{3}{|l|}{ Civil status } \\
\hline Single & 16 & 25 \\
\hline Married & 64 & 60 \\
\hline Divorced/separated & 11 & 10 \\
\hline Widowed & 6 & 5 \\
\hline \multicolumn{3}{|l|}{ Religion } \\
\hline Catholic & 68 & 60 \\
\hline Spiritism & 10 & 20 \\
\hline No religion & 12 & 15 \\
\hline Others & 10 & 5 \\
\hline \multicolumn{3}{|l|}{ Education } \\
\hline Elementary school & 1 & 5 \\
\hline College school & 13 & 5 \\
\hline University degree & 75 & 55 \\
\hline Post-graduate & 11 & 35 \\
\hline \multicolumn{3}{|l|}{ Period of work } \\
\hline Part-time & 50 & 30 \\
\hline Full-time & 46 & 65 \\
\hline Without answer & 4 & 5 \\
\hline Average work time in the area (years) & $16(1-44)$ & $11(1-15)$ \\
\hline
\end{tabular}


Table 2. Epilepsy clinical aspects according to teachers (the answers allowed more than one alternative).

\begin{tabular}{|c|c|c|}
\hline Epilepsy clinical aspects & Pre-test \% & Post-test $\%$ \\
\hline \multicolumn{3}{|l|}{ Percentage of controllable epilepsy } \\
\hline Do not know & 65 & 5 \\
\hline $80 \%$ & 14 & 60 \\
\hline $100 \%$ & 5 & 15 \\
\hline Others & 16 & 20 \\
\hline \multicolumn{3}{|l|}{ Epilepsy treatment } \\
\hline AEDs (antiepileptic drugs) & 67 & 95 \\
\hline Do not know & 24 & 15 \\
\hline Prayer & 3 & 0 \\
\hline Nothing & 3 & 0 \\
\hline Others & 3 & 0 \\
\hline \multicolumn{3}{|l|}{ Most common causes } \\
\hline High fever & 34 & 40 \\
\hline Brain infection & 31 & 40 \\
\hline Headache & 26 & 20 \\
\hline Head trauma & 24 & 80 \\
\hline Delivery problem & 32 & 60 \\
\hline Do not know & 32 & 0 \\
\hline \multicolumn{3}{|l|}{ Attitudes during a seizure } \\
\hline Turn over the person & 98 & 100 \\
\hline Pull the tongue & 24 & 5 \\
\hline Do not know how to proceed & 26 & 0 \\
\hline Call an ambulance if the seizure lasts more than $10 \mathrm{~min}$ & 53 & 70 \\
\hline \multicolumn{3}{|l|}{ Comparison of the IQ of children with epilepsy to others } \\
\hline Similar IQ (people with epilepsy and people without epilepsy) & 45 & 90 \\
\hline Above average & 18 & 0 \\
\hline Under average & 6 & 0 \\
\hline Do not know & 29 & 10 \\
\hline
\end{tabular}

same number thought that the government should act more effectively with this condition.

Table 2 summarizes clinical aspects of epilepsy according to teachers.

\section{Part III (perception)}

Figure 1 shows the teachers of group 1 (pre-test: 100 teachers) and 2 (post-test: 20 teachers after the course) with their beliefs about epilepsy. The teachers could choose one of five possible responses (totally agree, agree, no opinion, disagree, totally disagree).

\section{DISCUSSION}

Epilepsy is a chronic neurological condition, very common in children, which can have a high impact on quality of life. It can influence not only children, but also their families and their social and educational interactions ${ }^{13,25}$.

Teachers may shape the academic and personal development of their students ${ }^{26}$. It is interesting to highlight that lack of information, with myths and fears surrounding epilepsy and stigma has been identified in many locations ${ }^{1,4,14,18,20,27}$. Our results are in line with these finding and suggest that stigma with misleading beliefs and concepts regarding epilepsy also exist in this town of Brazil.

The belief that epilepsy is a contagious disease still persists in some places, such as Zimbabwe, Senegal and Nigeria ${ }^{28}$. Another concern in the educational area is the belief that a child with epilepsy may be more likely to have a mental disease in the future or the belief that epilepsy is an akin to mental disease. These beliefs, or irrational ideas, were 

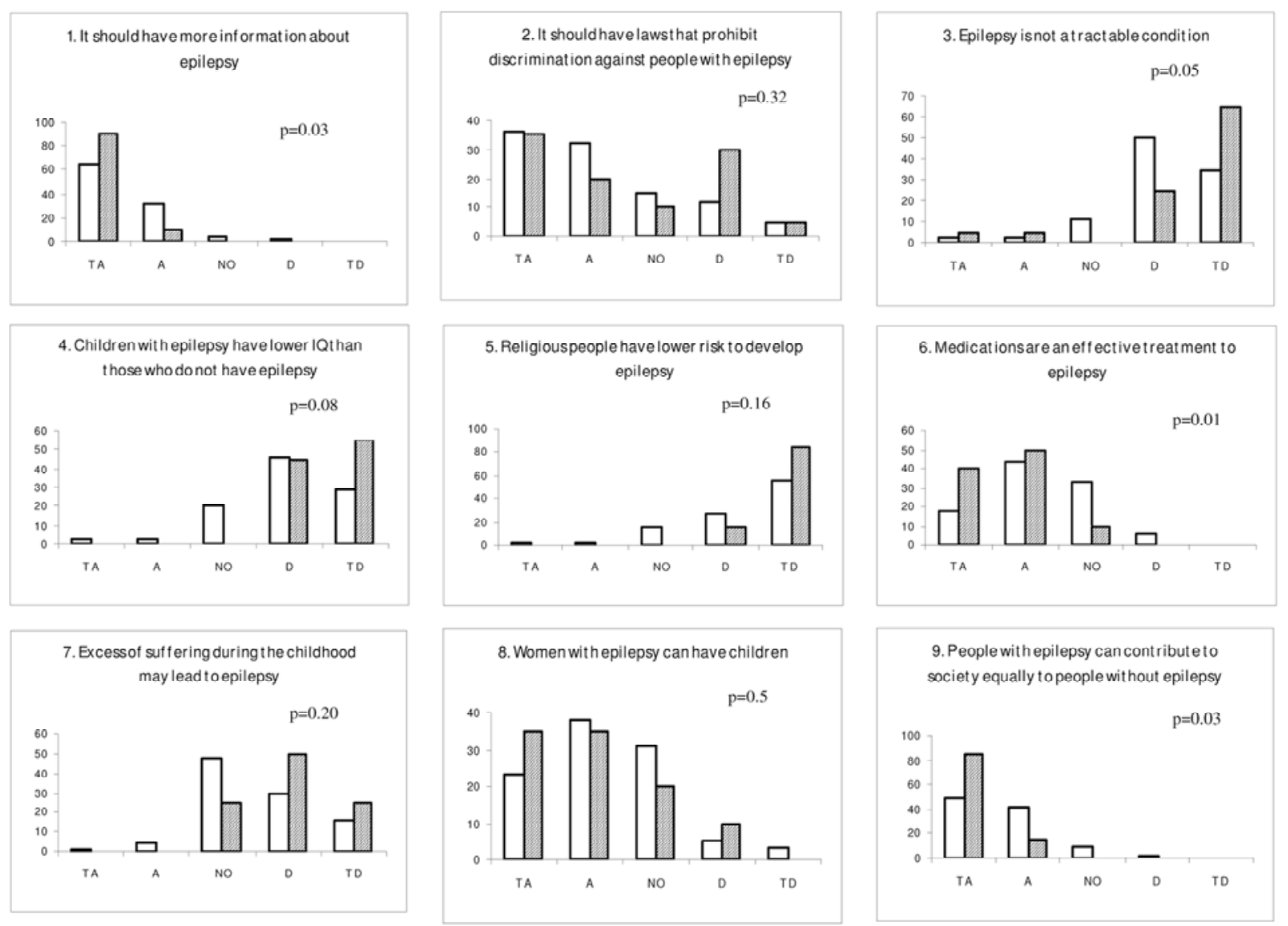

9. People with epilepsy can contribute to societ y equally to people without epilepsy

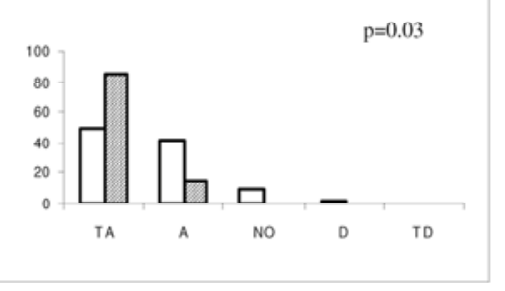

$$
\begin{aligned}
& \text { 10. The best thing to do ist o isolate people } \\
& \text { withepilepsy }
\end{aligned}
$$

11. If eel comf ort able allowing my son to have friendswith epilepsy

$\mathrm{p}<0.01$
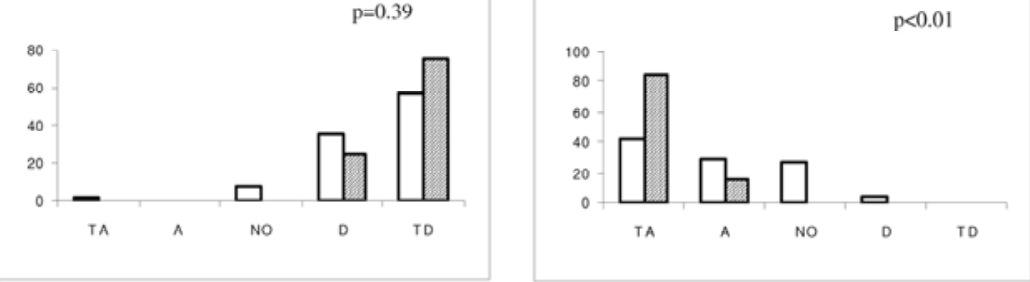

12.I Ibelief that epilepsy is a God'spunishment

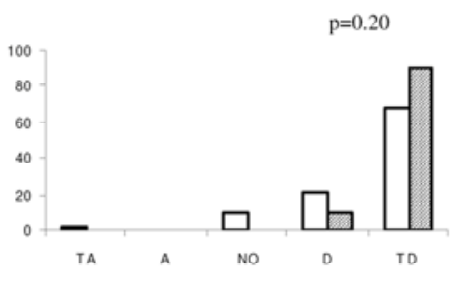

13. People with epilepsy can get married

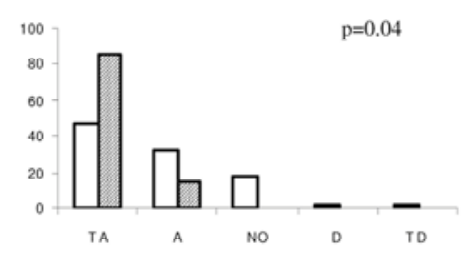

14. I prefer that people with epilepsy study in special schoole $p=0.09$

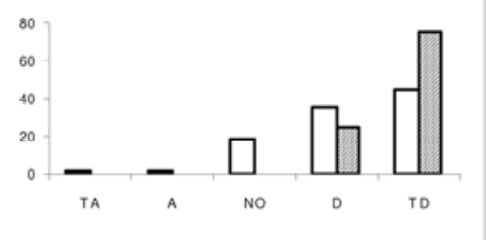

15. People with epilepsy have higher risk to becomeinsane in the future $\mathrm{p}=0.43$

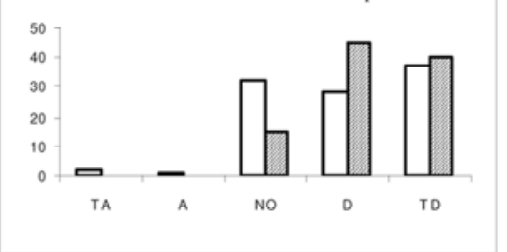

Fig 1. Perceptions regarding epilepsy (pre and post test). 


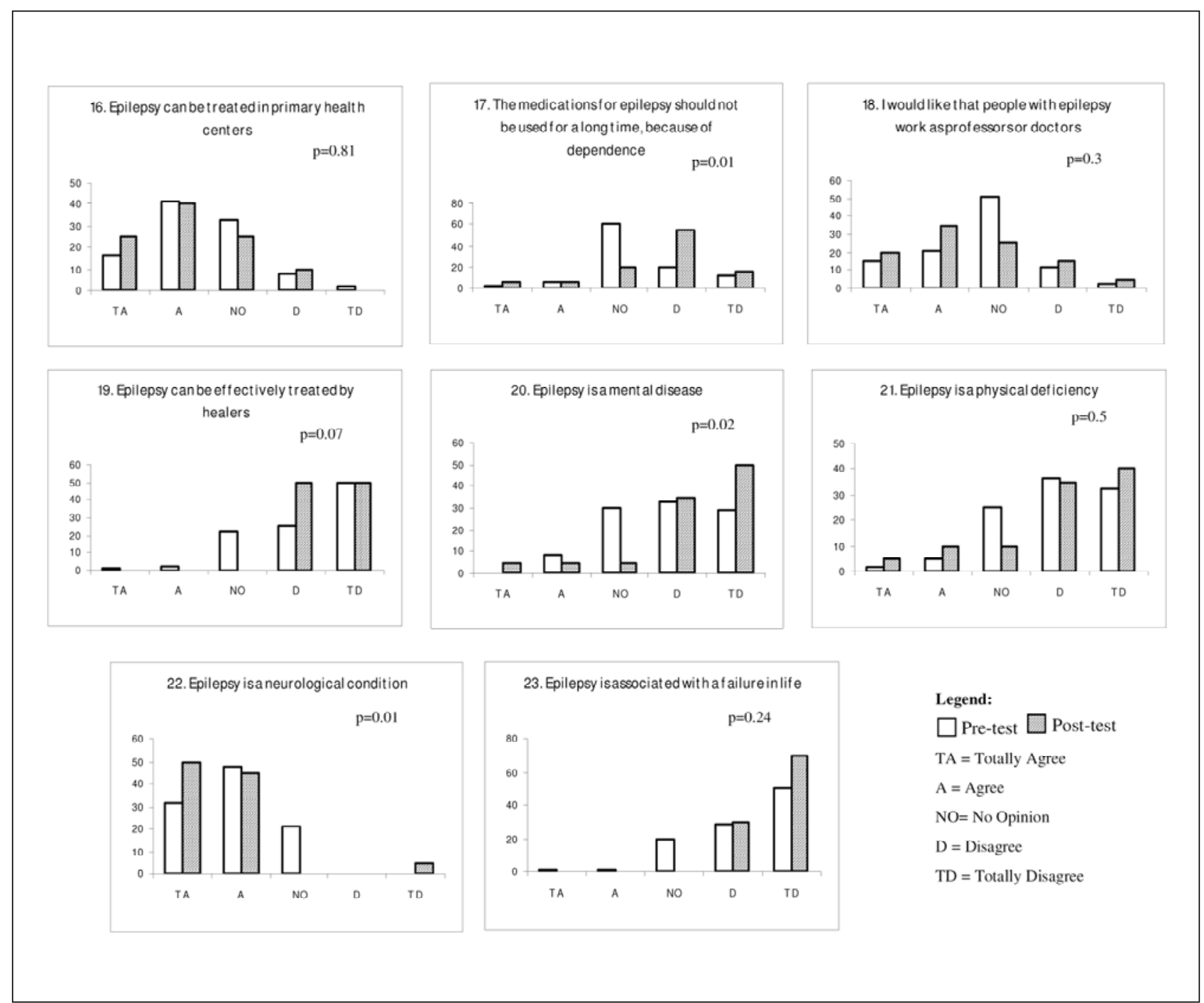

Fig 1 (continuation). Perceptions regarding epilepsy (pre and post test).

transmitted without scientific basis, originating from lack of knowledge about epilepsy and its treatment. These ideas can promote inappropriate behaviour, such as overprotection and feelings of fear, worry and insecurity, that can interf e re in the relationships and academic life of the child, increasing the perception of stigma ${ }^{17,29}$. Thus, it may be that if teachers have beliefs and myths about epilepsy they become confused and anxious about the way to deal properly with students with epilepsy ${ }^{30}$. Prpic ${ }^{4}$ has suggested that epilepsy causes a social effect in the person as a whole and that this may lead to stigma.

Another important point is the low expectation of children with epilepsy, along with the belief that children with epilepsy should study in special schools or classrooms. This attitude can be related to overp rotection or to stigma, and is a common pattern all over the world towards children with epilepsy ${ }^{31}$.
Furthemore, people believe these children are more fragile and may adopt behaviours to protect the chil$\mathrm{d}$ ren from frustrations and risks. This excessive care can lead to passive children and may influence their psycho-social adjustment ${ }^{8}$. Some teachers did not know how to proceed during a seizure; this may be the result of lack of experience with people with epilepsy. The lack of understanding of how to deal with epilepsy may cause low expectations in adults and low self-esteem in children with epilepsy,11,13.

Epilepsy is a concern not only for the child and the family, but also for teachers, who spend a lot of the time with them. In school problems relate to the restriction of activities, the fear of seizures and rejection of the child, which may accompanied by diff iculties in knowing how to manage children with epilepsy ${ }^{13}$. 
Our study investigates knowledge and expressed attitudes about epilepsy in a random sample of teachers. This study accords with previous ones; teachers have good information about epilepsy because of their level of education, but misconceptions and inappropriate behaviours still persist ${ }^{20}$. Two important aspects should be noted. Many teachers in this study did not have opinions about various aspects of epilepsy, such as treatment, causes, consequences and expectations, and this may be related to lack of information surrounding epilepsy and to poor educational programs in epilepsy. The questionnaire also had some theoretical questions and subjects may answer in a "politically correct" manner, according to social expectations.

Our results may explain why many children find barriers to developing their potential at school, which is not related to the disease or to medication side effects, but to the social attitudes, including stigma, related to them and their condition. This study reflects a part of the social attitude to epilepsy, as the teachers correspond to a group of educated professionals ${ }^{20}$, who should have adequate knowledge of, and attitudes towards, epilepsy. It should therefore be possible with a better educational program for these professionals to reduce the myths and fears about epilepsy, minimizing the effects of the associated stigma.

To summarize, erroneous opinions about epilepsy can be changed to the right perspective through public educational campaigns about epilepsy. This work with teachers in elementary school aims to identify the difficulties related to epilepsy for the pro motion of a better quality of life and the decrease of stigma. It is important that teachers should be better informed about epilepsy and consequently have mo re positive attitudes to it; educational campaigns must be encouraged ${ }^{20}$. We believe that more knowledgeable teachers can improve the management of epilepsy, and help to develop a well-informed and tolerant community.

\section{REFERENCES}

1. Olson AL, Seidler AB, Goodman D, Gaelic S, Nord g ren R. School professionals' perceptions about the impact of chronic illness in the classroom. Arch Pediatr Adolesc Med 2004;158:53-58.

2. Aldenkamp AP, Overweg-Plandsoen WC, Arends J. An open, nonrandomized clinical comparative study evaluating the effect of epilepsy on learning. J Child Neurol 1999;14:795-800.
3. Besag FM. Epilepsy and learning disabilities:closing comments. Epilepsia 2001;42(Suppl 1):59-61.

4. Prpic I, Korotaj Z, Vlasic-Cicvaric I, Paucic-Kirincic E, Valerjev A, Tomac V. Teachers' opinions about capabilities and behavior of children with epilepsy. Epilepsy Behav 2003;4:142-145.

5. Bourgeois BF. Antiepileptic drugs, learning, and behavior in childhood epilepsy. Epilepsia 1998;39:913-921.

6. Lefrève AB. Neurologia infantil: semiologia, clínica e tratamento. São Paulo: 1980.

7. Reynolds EH. ILAE/IBE/WHO Global Campaign "out of the shadows": global and regional developments. Epilepsia 2001;42:1094-1100.

8. Fernandes PT, Souza EA. Identification of family variables in parents' groups of children with epilepsy. A rq Neuropsiquiatr 2001;59:854-858.

9. Rosa MLR. Obstáculos percebidos por pais e professores no atendimento das necessidades de criança com epilepsia. Rev Latino-americana de Enfermagem 1997;5:37-44

10. Chung MY, Chang Y, Lai CW. Survey of public awareness, understanding, and attitudes toward epilepsy in Taiwan. Epilepsia 1995;36:488493.

11. Kankirawatana P. Epilepsy awareness among school teachers in Thailand. Epilepsia 1999;40:497-501.

12. Trimble MR, Dodson WE. Epilepsy and quality of life. New York: Raven Press, 1994.

13. Fernandes PT, Souza EA. Perception of epilepsy stigma in fundamental school teachers. Estudos de Psicologia 2004;9:189-195.

14. Ndour D, Diop AG, Ndiaye M, Niang C, Sarr MM, Ndiaye IP. A survey of school teachers' knowledge and behaviour about epilepsy, in a developing country such as Senegal]. Rev Neurol (Paris) 2004;160:338341.

15. Baker GA, Jacoby A, Buck D, Stalgis C, Monnet D. Quality of life of people with epilepsy: a European study. Epilepsia 1997;38:353-362.

16. Gumnit RJ. Living well with epilepsy. New York: Demos Vermande, 1997.

17. Devinsky O, Penry JK. Quality of life in epilepsy: the clinician's view. Epilepsia 1993;34:S4-S7.

18. Mielke J, Adamolekun B, Ball D, Mundanda T. Knowledge and attitudes of teachers towards epilepsy in Zimbabwe. Acta Neurol Scand 1997;96:133-137.

19. Mielke J, Sebit M, Adamolekun B. The impact of epilepsy on the quality of life of people with epilepsy in Zimbabwe: a pilot study. Seizure 2000;9:259-264.

20. Ojinnaka NC. Teachers' perception of epilepsy in Nigeria: a community based-study. Seizure 2002;11:386-391.

21. Cunha, R. Educação especial tenta afastar estigma da epilepsia. Revista ComCiência 2002;34:54-56.

22. Hsieh LP, Chiou HH. Comparison of epilepsy and asthma perception among preschool teachers in Taiwan. Epilepsia 2001;42:647-650.

23. Li LM, Sander JW. National demonstration project on epilepsy in Brazil. Arq Neuropsiquiatr 2003;61:153-156.

24. Bunchaft G, Cavas CST. Sob medida: um guia de elaboração de medidas do comportamento e suas aplicações. 2002.

25. Hanai T. Quality of life in children with epilepsy. Epilepsia 1996;37: 28-32.

26. Bannon MJ, Wildig C, Jones PW. Teachers' perceptions of epilepsy. Arch Dis Child 1992;67:1467-1471.

27. Bekiroglu N, Ozkan R, Gurses C, Arpaci B, Dervent A. A study on aw a reness and attitude of teachers on epilepsy in Istanbul. Seizure 2004;13:517-22.

28. Global campaign against epilepsy. World Health Forum 1998;19: 107-108.

29. Souza EA, GuerreiroCA. Qualidade de vida e epilepsia. In: Guerrei ro CAM, Guerreiro MM, Cendes F, Lopes-Cendes I (Eds). Epilepsia. São Paulo: Lemos Editorial, 2000:223-229.

30. Dantas FG, Cariri GA, Cariri GA, Ribeiro Filho ARV. Knowledge and attitudes toward epilepsy among primary, secondary and tertiary levels teachers. Arq Neuropsiquiatr 2001;59:712-716.

31. Fejerman N, Caraballo R. Impacto de la epilepsia en el niño y su familia. In: Devilat M, ed. La epilepsia en LatinoAmerica. Santiago de Chile: Iku Editorial, 2000:245-254. 